\title{
Discovery of $\sim 4.0$ Ga detrital zircons in the Changdu Block, North Qiangtang, Tibetan Plateau
}

\author{
HE ShiPing ${ }^{1,2^{*}}$, LI RongShe ${ }^{1}$, WANG Chao ${ }^{1}$, ZHANG HongFei ${ }^{2}$, JI WenHua ${ }^{1}$, YU PuSheng ${ }^{1}$, \\ GU Ping Yang ${ }^{1} \&$ SHI Chao ${ }^{1}$
}

${ }^{1} X i$ 'an Institute of Geology and Mineral Resources, Xi'an 710054, China;

${ }^{2}$ Faculty of Earth Science, China University of Geosciences, Wuhan 430074, China

Received August 10, 2010; accepted December 3, 2010

\begin{abstract}
Using in situ zircon dating by LA-ICP-MS and MC-ICP-MS, detrital zircon of 3981 \pm 9 Ma age was found in metamorphic rocks of the Ningduo Rock Group, Changdu Block of Northern Qiangtang. This is the oldest age record that has been found in the Qiangtang area. This finding also constitutes the third zircon locality in China with an age older than 3.9 Ga. Thus, the discovery provides new information for the study of Hadean crust. In addition, we found 3.51-3.13 Ga, 2440 Ma, 1532 Ma, $982 \mathrm{Ma}$ and $\sim 618 \mathrm{Ma}$ age peaks from 100 test spots. The younger ages of $\sim 982 \mathrm{Ma}$ and $\sim 618 \mathrm{Ma}$ correspond to the formation of the Rodinian super-continent and the Pan-African event, respectively. These findings suggest a close relationship between these zircons and the Gondwanan super-continent. The age of $\sim 618 \mathrm{Ma}$ defines the lower limit on the deposit time of the protolith for the garnet-micaquartz schist in the Ningduo Rock Group. Zircons with an age of $\sim 982 \mathrm{Ma}$ generally display a negative $\varepsilon_{\mathrm{Hf}}(t)$ and a two-stage Hf model with concentrated ages around 1933-2553 Ma. This pattern indicates that the source area of the Ningduo Rock Group underwent a significant separation of depleted mantle into the crust during the Paleoproterozoic Era. However, zircons with ages of 2854-3505 Ma also show a negative $\varepsilon_{\mathrm{Hf}}(t)$ and a two-stage $\mathrm{Hf}$ model with a concentration of ages around 3784-4316 Ma. These results demonstrate that the source area of the Ningduo Rock Group contains a residual amount of ancient (Hadean) crustal materials. This paper provides new information on the relationship between the basement of the Qiangtang area and the Paleoproterozoic basements of the Gangdese and Himalayan regions, which constrains the northern boundary of Gondwana.
\end{abstract}

\section{Changdu Block, Ningduo Rock Group, Hadean, detrital zircons, LA-ICP-MS, Hf isotopes}

Citation: He S P, Li R S, Wang C, et al. Discovery of $\sim 4.0$ Ga detrital zircons in the Changdu Block, North Qiangtang, Tibetan Plateau. Chinese Sci Bull, 2011, 56: 647-658, doi: 10.1007/s11434-010-4320-z

Exploring the formation and early evolution of the Earth has been an important part of Earth science research. This type of research has involved a series of important scientific studies [1], including identification of when the first continent formed, the nature of this material, and whether recycling between crust and mantle existed during the early evolution of the Earth. Complex and diverse geological processes over time have resulted in a limited distribution of rocks formed during the Hadean (4.56-3.85 Ga) [2,3]. Until now, crustal rocks with age of more than $3.8 \mathrm{Ga}$ only have

*Corresponding author (email: xakeyi@163.com) been discovered in Greenland [4,5], Canada [6,7], Anshan in China [8-10] and Eastern Antarctica [11-13]. The oldest rocks that have been found on Earth are from the Acasta gneiss of the Wopmay orogenic belt in Canada, and they have been dated to $4016 \mathrm{Ma}$ [14]. Although there are limited records of rocks surviving from early Earth, abundant ancient zircon residues have been found within younger geologic bodies [15]. After a long exploration, a series of detrital zircons with ages of $\geqslant 3.8 \mathrm{Ga}$ have been discovered in the northeastern Bavaria region in Germany [16], northern Wyoming, USA [17], the Yilgarn craton of Western Australia [18], the San Francisco craton in Brazil [19], the 
high Himalayan region to the west of Nepal [20], and north of Kazakhstan [21]. Undoubtedly, this information has provided an excellent set of data to investigate the evolution of crustal rocks formed during early Earth.

In recent years, important progress has been made in the search for and study of extremely ancient rock materials in China. Since the discovery of the TTG rocks of $3.8 \mathrm{Ga}$ in the Anshan area at the end of the last century, several detrital zircons with ages of $\geqslant 3.8 \mathrm{Ga}$ have been reported, including in Qianxi County in the Hebei Province [1,22,23], Pulan County in Tibet [24,25], Yichang in the Hubei Province [26], Liangdang County in the Gansu Province [27], and Pingle-Beijiang in southeast Guangdong Province [28]. The discovery of the oldest Chinese zircons of $4.1 \mathrm{Ga}$ in Pulan County in the Himalayan Orogeny, and in Liangdang County in North Qinlin orogenic belt, significantly contributed to research of ancient Earth materials.

Using LA-ICP-MS, we obtained detrital zircon of $3981 \pm 9$ Ma in the Ningduo Rock Group of the Changdu Block, northern Qiangtang area, Tibetan Plateau. This is the oldest age that has been recorded in the Qiangtang area, the hinterland of Tibet, and is the third oldest zircon suite in China, after the discoveries in Tibet and Qinling. These findings significantly contribute to the study of the formation and evolution of the early crust and for investigating the nature of the basement of Qiangtang.

\section{Regional geological setting}

The study area is located in the Changdu Block of northern Qiangtang in Tibet, and lies between the XijinwulanJinshajiang and Bangonghu-Nujiang suture zones in western Yushu County, Qinghai Province (Figure 1). The Changdu Block is a narrow, NE-trending belt situated along the south of the Bayankala orogenic belt. Because of the MesozoicCenozoic cover and the fractured dislocation of Precambrian basement rocks toward the NW-SE, they are scattered as faulted blocks, mainly consisting of the Ningduo and the Xiongsong rock groups. The "Southwest Regional Stratigraphy" project has provided a revision of Precambrian stratigraphic sequences of this region, and concluded that the Xiongsong and Ningduo rock groups are synonymous [29], such that the "Xiongsong Rock Group" (named in Mangkang County-Batang County) now belongs in the Ningduo Rock Group. Consequently, the basement of the Changdu Block is composed of only the Ningduo Rock Group, which is distributed mainly in Duocai, Zhiduo County, Qinghai Province; Longbao and Xiaosumang, Yushu County; the Jinshajiang region in western Gongjue County-Mangkang County; and eastern Jiangda CountyBatang County on the border between Tibet and Sichuan.

This paper focuses on the Ningduo Rock Group in Longbao (Zanie), Yushu County, Qinghai Province. The Ningduo Rock Group in this area appears as a narrow belt located between the Xiewu Ophiolite mélange zone and the Longbao ophiolite mélange zone, and mainly consists of high-grade greenschist to low-grade amphibolite facies metamorphic rocks, such as biotite plagioclase gneiss, garnet-mica quartz schist, quartzite, granulite with amphibolite schist, and chlorite-amphibole schist. The occurrence of these rock types is at $170^{\circ} \angle 62^{\circ}$. The protolith mainly consists of sedimentary clastic rocks, basic-intermediate volcanic rocks, and carbonate rock formations with high maturity. The age of the Ningduo Rock Group has long been disputed. Previous surveys have classified the Qinghai Province into the upper Paleozoic. The 1:200000 regional geological survey [30,31] inferred that the Ningduo Rock Group should be placed in the Paleo-Mesoproterozoic. This suggestion is based on zircon U-Pb ages of $2200 \pm 140 \mathrm{Ma}$ from two-mica plagioclase gneiss in Xiariduo, $1870 \pm 280$ Ma from biotite plagioclase gneiss in the Changkeqing area, and $1780 \pm 150 \mathrm{Ma}$ and $1680 \pm 309 \mathrm{Ma}$ from gneissic biotite granite in Dasumang and Xiaosumang. However, the 1:250000 regional geological survey of Zhiduo and Qurougaka obtained a single zircon with ages of $709 \pm 66 \mathrm{Ma}$ [32] and 835-915 Ma [33], which are considered to be the metamorphic age of the Ningduo Rock Group. Based on the above isotopic ages, rock associations, metamorphism, nonlayered deformation characteristics, and regional stratigraphic correlations, we tentatively placed the Ningduo Rock Group in the Meso-Neoproterozoic [34].

Two ophiolite mélange zones extend along the NW-SE portion of the study region. Both are dismembered from the Tongtianhe ophiolite mélange zone in the 1:250000 regional geological survey of Yushu [35]. Regionally, these are equivalent to part of the Xijinwulan-Jinshajiang suture zone. Following later tectonic events, the Ningduo Rock Group was strongly fractured and foliated, and integrated into a mélange belt of the Longbao ophiolite in form of rock blocks. The northwest-trending faults are well-developed in this region, and constitute boundaries among different stratal units. A great number of diabase-babbro dykes are found in the northwest. They intruded the epimetamorphic clastic rocks with medium basic to medium acidic volcanic lava and volcaniclastic rocks of the Yiji Formation in the early Devonian.

\section{Isotope dating}

\subsection{Sample collection}

The detrital zircons used for isotope dating were collected in the western part of a N-S trending valley, about $45 \mathrm{~km}$ away from northwest Yushu County in the Qinghai Province $\left(33^{\circ} 14^{\prime} 27.5^{\prime \prime} \mathrm{N}, 96^{\circ} 35^{\prime} 24^{\prime \prime} \mathrm{E}, 4520 \mathrm{~m}\right)$. The sample collected from the Ningduo Rock Group was a garnetmica quartz schist (sample No. 07ND-1, about $28 \mathrm{~kg}$ ). It was pale gray, mainly with a scaly granular texture, schistose structure, crumpled deformation, and kink phenomenon 


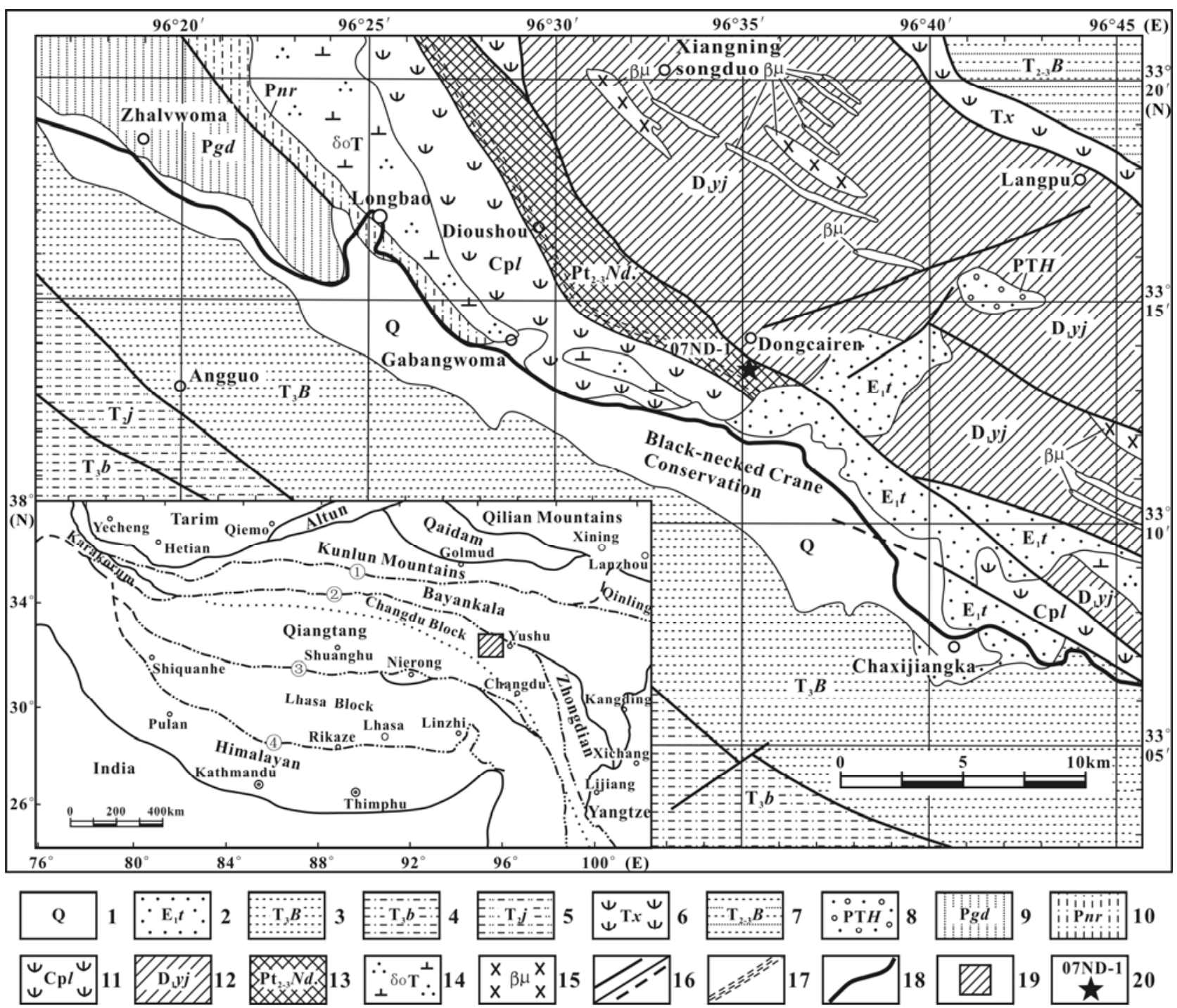

Figure 1 Schematic map of the Longbao area in Yushu County, Changdu Block, North Qiangtang (from 2004 geological survey map at a scale of 1:250000, Yushu sheet). 1, Quaternary; 2, Tuotuohe Formation of Paleogene age; 3, Batang Group of Late Triassic age; 4, Bolila Formation of Late Triassic age; 5, Jilong Formation of Middle Triassic age; 6, Xiewu Ophiolite mélange of Triassic age; 7, Bayankalashan Group of Middle-Late Triassic age; 8, Hantaishan Group of PermianTriassic age; 9, Gadikao Formation of Permian age; 10, Nuoribagaribao Formation of Permian age; 11, Longbao Ophiolite mélange of Carboniferous-Permian age; 12, Yiji Formation of early Devonian age; 13, Ningduo Rock Group of Meso-Neoproterozoic age; 14, Triassic quartz diorite; 15, Gabbro-diabase; 16, faults or inferred faults; 17, ductile shear zones; 18, road; 19, study area; 20, sampling locations and control numbers; (1) suture of Kangxiwa-Muzitage-Maqin-Mianxian-Lueyang; (2) suture of Xijinwulan-Jinshajiang; (3) suture of Bangonghu-Nujiang; (4) suture of Yaluzangbujiang.

developed in the mica minerals. The minerals included mainly biotite $(24 \% \pm)$, muscovite $(20 \% \pm)$, quartz $(45 \% \pm)$, and a small amount of garnet $(10 \% \pm)$ and zircon $(<1 \%)$. The protolith consisted of clastic sedimentary rocks.

\subsection{Analytical methods}

The selection of a single mineral zircon was accomplished in the Langfang Laboratory, Hebei Bureau of Geology and Mineral Resources, Minister of Land and Resources. The sample (07ND-1) was crushed to pass through a 20-30 mesh. About 180 grains of zircon were obtained after flotation and magnetic separation. A total of 120 zircons with no cracks or inclusions were selected under a binocular microscope for further tests. These samples were embedded into epoxy and polished to expose the internal structures of zircon grains. Before zircon U-Pb dating with LA-ICP-MS and MC-ICP-MS, reflected and transmitted light microscopy and cathodoluminescence (CL) image analyses were undertaken.

Zircon CL images were taken at the State Key laboratory of Continental Dynamics, Northwest University. The micrographs of the internal structures of zircons were produced with a Cathode-fluorescent spectrometer (Mono CL3+) manufactured by Gatan in the United States.

The zircon $\mathrm{U}-\mathrm{Pb}$ and $\mathrm{Lu}-\mathrm{Hf}$ isotopic compositions were 
analyzed at the State Key Laboratory of Continental Dynamics, Northwest University. The test spots from 07ND-101 to 07ND-1-60 were undertaken by LA-ICP-MS, using 30 $\mu \mathrm{m}$ laser beam ablation. However, the spots from 07ND-1$1 \mathrm{~b}$ to $07 \mathrm{ND}-1-68 \mathrm{~b}$ were tested by MC-ICP-MS, with $44 \mu \mathrm{m}$ laser beam ablation. The isotope ratios and element contents were calculated with Glitter software (Ver4.0, Macquarie University). According to the method of Andersen [36], isotopic ratio corrections were conducted to eliminate the effects of common lead. Based on the average crustal $\mathrm{Pb}$ isotopic composition given by Stacey, we corrected the isotopic ratio and common lead. Concordia age calculations and mapping were achieved with Isoplot (Ver3.0) [37]. Additional detailed equipment characteristics and analytical procedures are found in [38-40].

\subsection{Zircons}

Most zircons collected from the garnet-mica quartz schist (07ND-1) in the Ningduo Rock Group were rounded (some of the defects may have been caused by mechanical damage during sample grinding), with great difference in size $(60-180 \mu \mathrm{m})$ and color variations (from light brown, light smoky gray, light yellow, light pink to colorless). These variations indicate a multi-source for these detrital zircons.

From the CL images, it is clear that the majority of the zircons appeared rounded and had developed internal zonation (Figure 2), a characteristic of origination from a magma
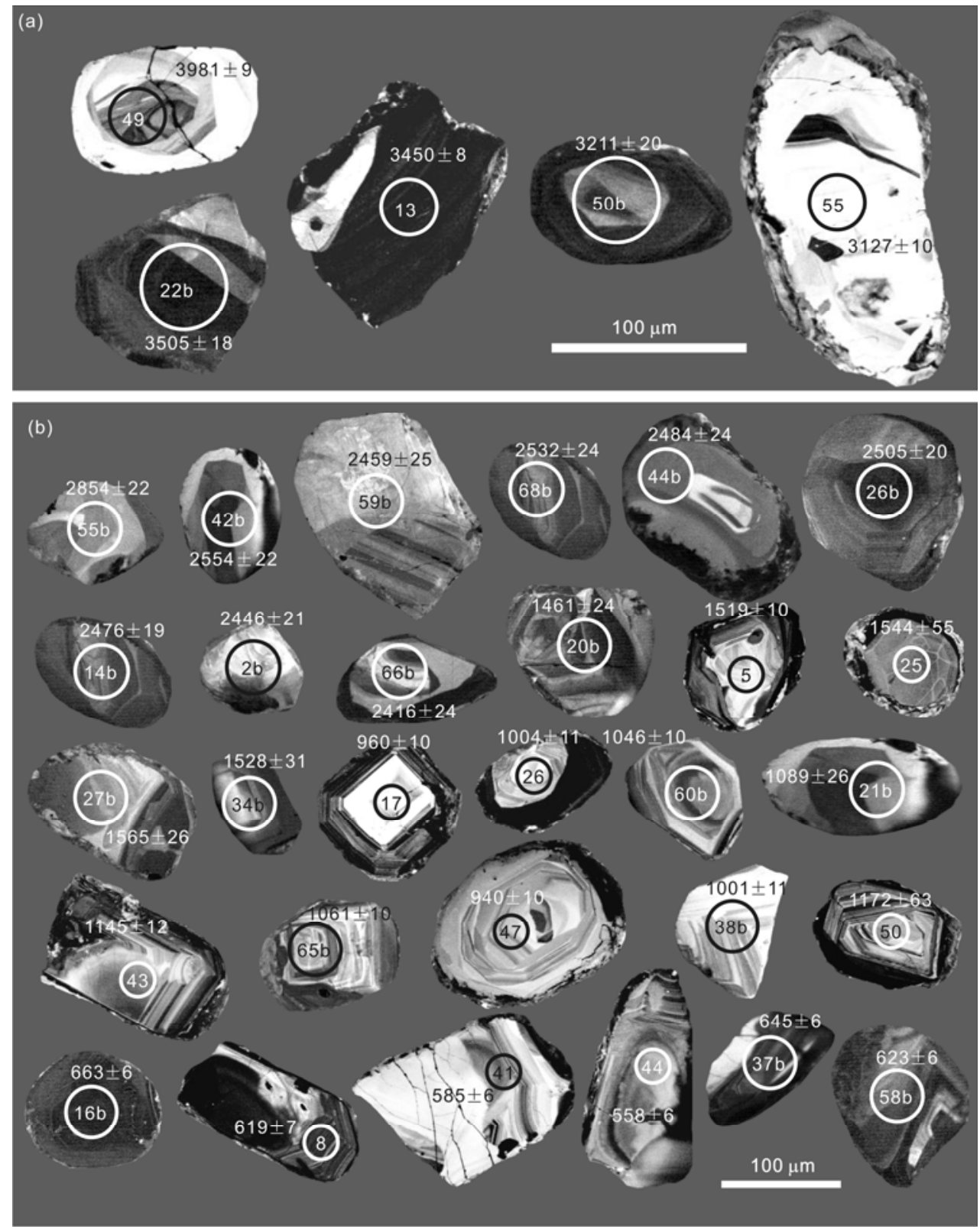

Figure $2 \mathrm{CL}$ images of the detrital zircons with ages (a) $>3100 \mathrm{Ma}$ and (b) $<3100 \mathrm{Ma}$. The circles indicate the test spots, the unit of the measured age is $\mathrm{Ma}$, using ${ }^{207} \mathrm{~Pb} /{ }^{206} \mathrm{~Pb}$ and ${ }^{206} \mathrm{~Pb} /{ }^{238} \mathrm{U}$ for age measurements $>1000 \mathrm{Ma}$ and $<1000 \mathrm{Ma}$. 
source. A few zircons (14b, 26b, 27b, 68b) developed fuzzy and wide internal zonation, which may have been caused by later alterations. Individual zircons $(2 \mathrm{~b}, 42 \mathrm{~b}, 66 \mathrm{~b})$ had mottled structures, and some $(13,50 \mathrm{~b}, 44 \mathrm{~b})$ had a kernel. Some zircons with ages $>900$ Ma $(5,25,26,47,50,44 \mathrm{~b}, 66 \mathrm{~b})$ were surrounded by dark overgrowths, revealing that they never underwent strong tectono-thermal events. The No. 49 (Figure 2(a)) zircon appeared rounded and showed a welldeveloped core, mantle and rim structure, which indicates multi-growth.

\subsection{Zircon U-Pb dating}

Of the 128 total test spots for the detrital zircons collected from the garnet-mica quartz schist of the Ningduo Rock Group, 28 spots $(4,7,28,30,35,39,40,46,48,53,57,59$, 3b, 6b, 13b, 17b, 24b, 28b, 29b, 32b, 33b, 39b, 41b, 46b, 51b, $53 \mathrm{~b}, 54 \mathrm{~b}, 67 \mathrm{~b}$ ) were rejected because of the over proportion value of ${ }^{204} \mathrm{~Pb}$ and low concordia degree (including $<90$ and $>110$ ). Thus, 100 valid test spots remained (Table 1 ).

There were a few ancient detrital zircons in the garnet-mica quartz schist of the Ningduo Rock Group (07ND1 ), and the oldest zircon (No. 49) appeared with a coremantle-rim structure. The ${ }^{207} \mathrm{~Pb} /{ }^{206} \mathrm{~Pb}$ age of $3981 \pm 9 \mathrm{Ma}$ was tested in the core. The test spot was located below and close to the concordia line in the graph (Figure 3(a)), and the concordia degree was 94, which implies slight loss of radiogenic lead. In addition, there were four ancient ${ }^{207} \mathrm{~Pb} /{ }^{206} \mathrm{~Pb}$ ages of the detrital zircons: $(3505 \pm 18-3127 \pm 10$ Ma [No. 22b, 13, 50b, 50]).

The zircon U-Pb concordia diagram (Figure 3(a)) and the chart of age frequency distribution (Figure 3(b)) showed that the concordia ages concentrate in four groups: 1200$850 \mathrm{Ma}$, with a peak age of about $982 \mathrm{Ma}$. Most of the test spots in this group were located in or adjacent to the concordia line, and most of the zircons in this group were rounded, and had developed internal oscillatory zonation (Figure 2(b)), with higher Th/U ratios (generally in 0.314.67). This information suggests that these zircons came from a magma source that experienced the Grenville tec-

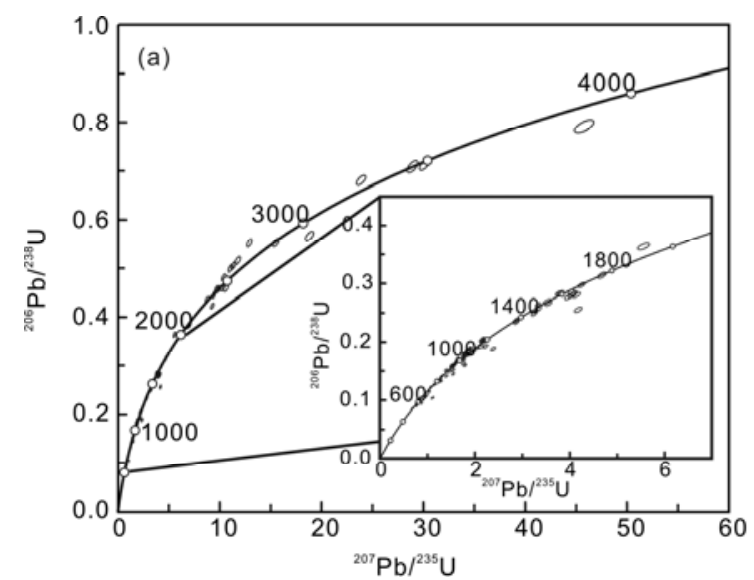

tono-magmatic events. Another ${ }^{206} \mathrm{~Pb} /{ }^{238} \mathrm{U}$ age group was 700-530 Ma, and the peak age was $\sim 618 \mathrm{Ma}$. These samples had rounded to angular zircons with developing zonation (Figure 2(b)), and higher $\mathrm{Th} / \mathrm{U}$ ratios (0.38-5.92). In addition, the ${ }^{207} \mathrm{~Pb} /{ }^{206} \mathrm{~Pb}$ ages were found to be around 2600-2300 Ma and 1700-1400 Ma, and the age peaks were $\sim 2440 \mathrm{Ma}$ and $\sim 1532 \mathrm{Ma}$. These zircons were rounded, had wide developing internal zonation, and higher $\mathrm{Th} / \mathrm{U}$ ratios (0.33-1.23 and 0.23-2.50). From these results, it can be concluded that these zircons came from a source that experienced tectono-magmatic events occurring about 618, 2440 and 1532 Ma BP.

\subsection{Hf isotopes}

There were 68 test spots obtained for the Lu-Hf isotope test on zircons from the garnet-mica quartz schist of the Ningduo Rock Group. A total of 18 spots $(3 \mathrm{~b}, 5 \mathrm{~b}, 6 \mathrm{~b}, 13 \mathrm{~b}, 17 \mathrm{~b}$, 23b, 24b, 28b, 29b, 32b, 33b, 39b, 41b, 46b, 51b, 53b, 54b, $67 \mathrm{~b})$ were rejected because of low confidence in the data caused by low Hf contents. Thus, 50 valid test spots remained (Table 2). The low ${ }^{176} \mathrm{Lu} /{ }^{177} \mathrm{Hf}$ ratio (mostly <0.002) in all zircons showed that there was lower accumulation of radiogenic Hf after their crystallization. The data on the ${ }^{176} \mathrm{Hf} /{ }^{177} \mathrm{Hf}$ ratios can be divided into four groups (Figure 4(a)). Firstly, zircons with ages concentrating around 2440 Ma show low ${ }^{176} \mathrm{Hf} /{ }^{177} \mathrm{Hf}$ ratios $(0.280456-0.281269)$ and negative $\varepsilon_{\mathrm{Hf}}(t)(-3.2$ to -25.6$)$. The two-stage model ages $T_{\mathrm{DM} 2}$ (3039-4584 Ma) were all greater than their crystal ages. Secondly, zircons with ages around 1532 Ma also displayed low ${ }^{176} \mathrm{Hf} /{ }^{177} \mathrm{Hf}$ ratios $(0.281313-0.281826)$, and their $\varepsilon_{\mathrm{Hf}}(t)(-0.4$ to -18.4$)$ were all negative except for one, 0.7. The two-stage model ages $T_{\mathrm{DM} 2}(2296-2284 \mathrm{Ma})$ were all greater than their crystal ages. Thirdly, zircons formed during Grenville time had high ${ }^{176} \mathrm{Hf} /{ }^{177} \mathrm{Hf}$ ratios $(0.281406-$ $0.282441)$. The $\varepsilon_{\mathrm{Hf}}(t)$ and the two-stage model ages $T_{\mathrm{DM} 2}$ yielded 27.9 to 9.8 and 1234 to 3533 Ma. Fourthly, zircons with ages concentrated around $\sim 618 \mathrm{Ma}$ revealed low ${ }^{176} \mathrm{Hf} /{ }^{177} \mathrm{Hf}$ ratios $(0.281637-0.282023)$ and negative $\varepsilon_{\mathrm{Hf}}(t)$ ( -13.0 to -32.4$)$. The two-stage model ages $T_{\mathrm{DM} 2}$ yielded

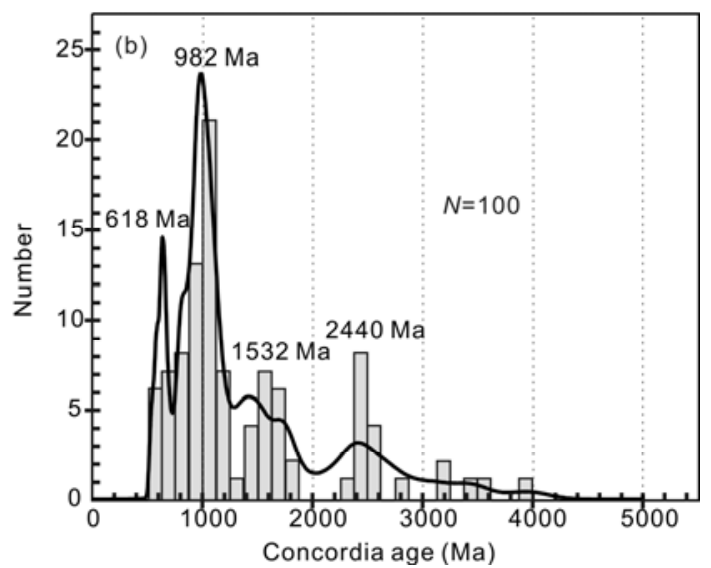

Figure 3 Concordia graph (a) and frequency chart (b) for detrital zircons in the garnet-mica quartz schist of the Ningduo Rock Group. 


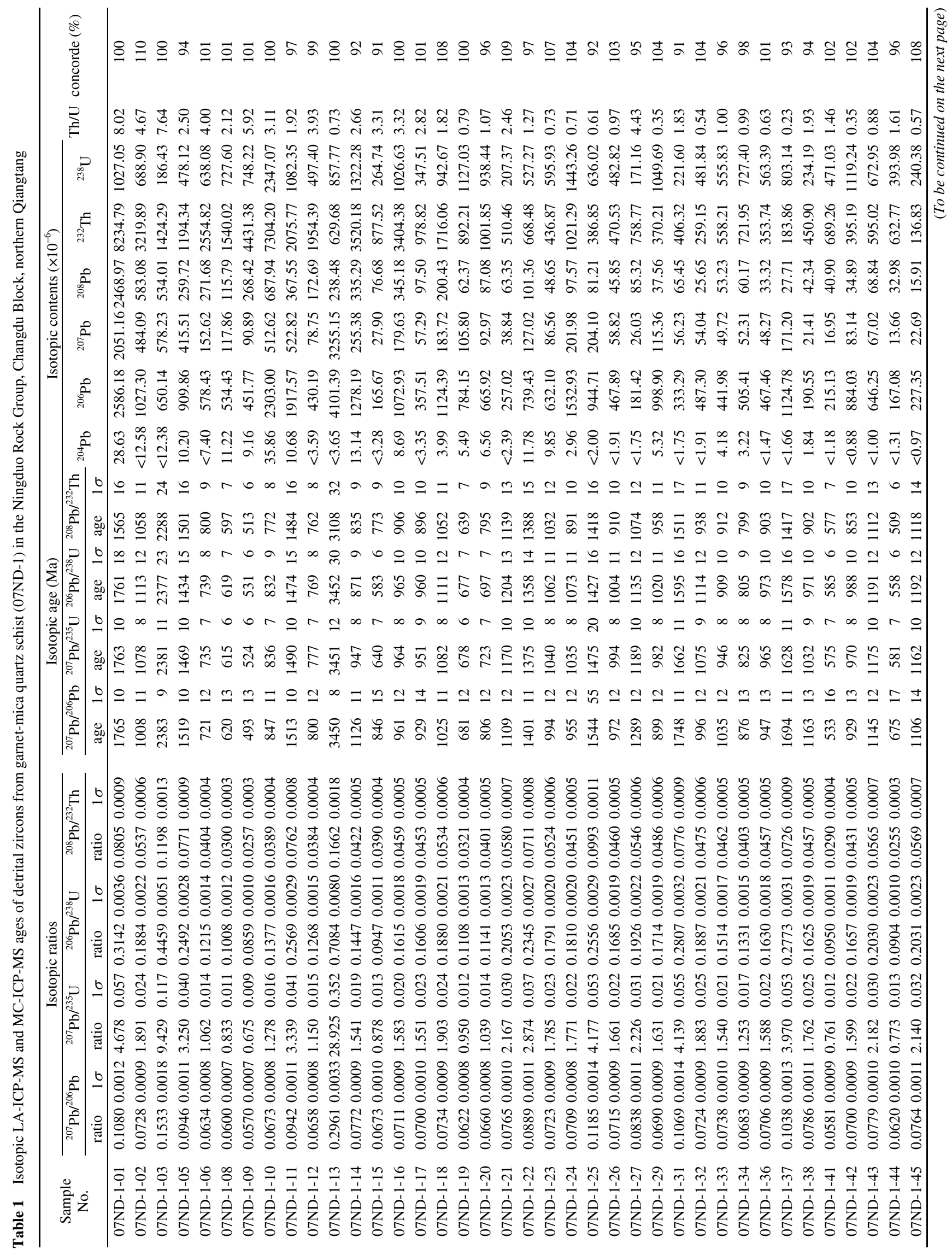




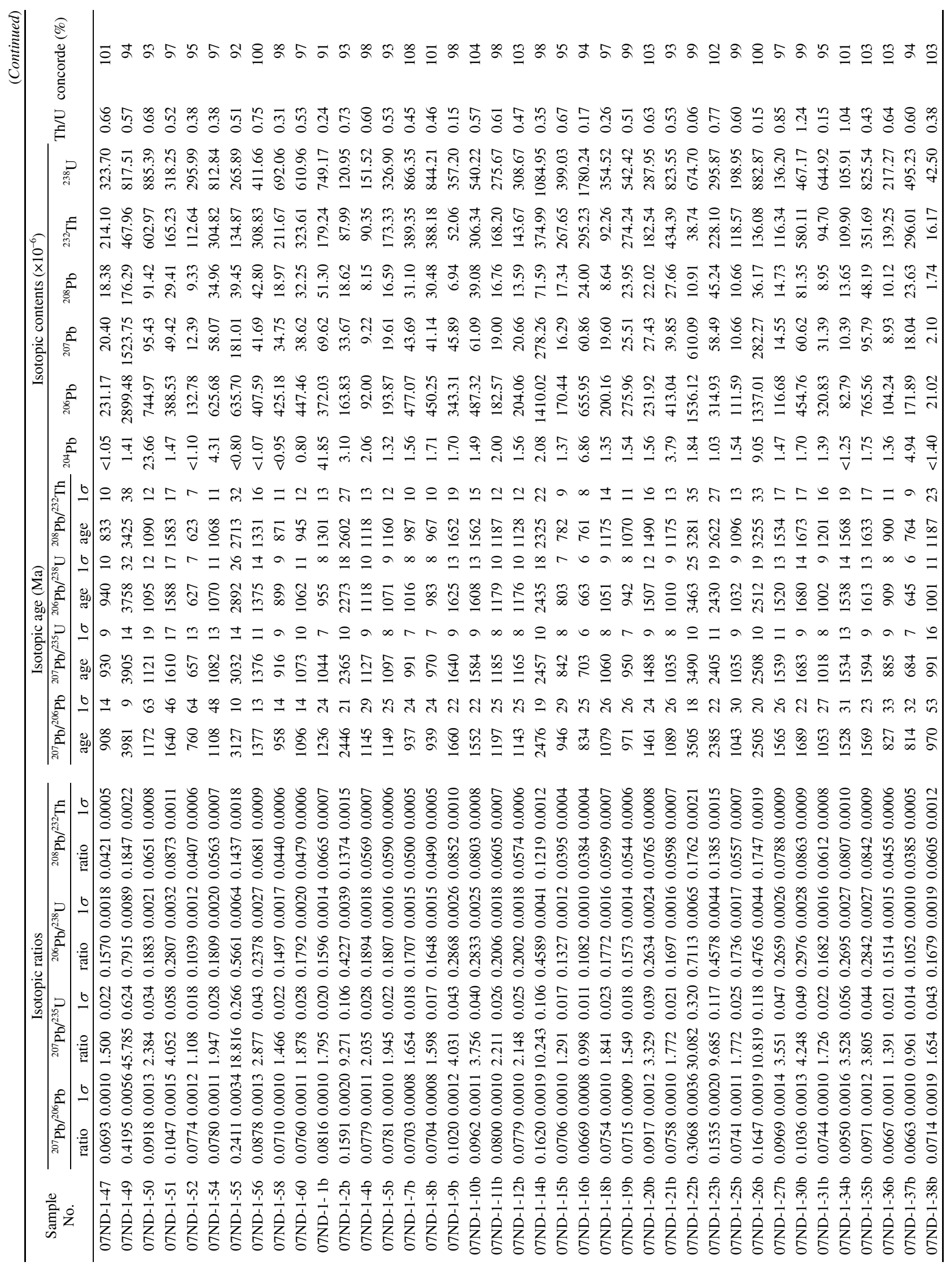


Table 2 Lu-Hf isotopes of detrital zircons of garnet-mica schist (07ND-1) in the Ningduo Rock Group in Changdu Block, northern Qiangtang

\begin{tabular}{|c|c|c|c|c|c|c|c|c|c|c|c|}
\hline Sample No. & Age (Ma) & ${ }^{176} \mathrm{Yb} /{ }^{177} \mathrm{Hf}$ & ${ }^{176} \mathrm{Lu} /{ }^{177} \mathrm{Hf}$ & ${ }^{176} \mathrm{Hf} /{ }^{177} \mathrm{Hf}$ & $2 \sigma$ & $\varepsilon_{\mathrm{Hf}}(0)$ & $\varepsilon_{\mathrm{Hf}}(t)$ & $2 \sigma$ & $T_{\mathrm{DM} 1}$ & $T_{\mathrm{DM} 2}$ & $f_{\mathrm{Lu} / \mathrm{Hf}}$ \\
\hline 07ND-1-1b & 955 & 0.03044 & 0.00116 & 0.281967 & 0.000022 & -28.5 & -8.1 & 0.8 & 1816 & 2320 & -0.96 \\
\hline $07 \mathrm{ND}-1-2 \mathrm{~b}$ & 2446 & 0.01324 & 0.00052 & 0.281091 & 0.000019 & -59.4 & -5.5 & 0.7 & 2972 & 3294 & -0.98 \\
\hline 07ND-1-4b & 1145 & 0.03500 & 0.00132 & 0.281815 & 0.000029 & -33.8 & -9.5 & 1.0 & 2036 & 2551 & -0.96 \\
\hline 07ND-1-7b & 1016 & 0.02246 & 0.00083 & 0.281936 & 0.000021 & -29.6 & -7.7 & 0.7 & 1843 & 2339 & -0.97 \\
\hline 07ND-1-8b & 983 & 0.02092 & 0.00078 & 0.281938 & 0.000019 & -29.5 & -8.3 & 0.7 & 1838 & 2352 & -0.98 \\
\hline 07ND-1-9b & 1660 & 0.02991 & 0.00116 & 0.281589 & 0.000023 & -41.8 & -6.2 & 0.8 & 2340 & 2737 & -0.96 \\
\hline 07ND-1-10b & 1552 & 0.03797 & 0.00139 & 0.281826 & 0.000021 & -33.5 & -0.4 & 0.7 & 2024 & 2296 & -0.96 \\
\hline 07ND-1-11b & 1197 & 0.01957 & 0.00074 & 0.281915 & 0.000022 & -30.3 & -4.4 & 0.8 & 1868 & 2272 & -0.98 \\
\hline $07 \mathrm{ND}-1-12 \mathrm{~b}$ & 1143 & 0.03628 & 0.00143 & 0.281089 & 0.000028 & -59.5 & -35.4 & 1.0 & 3046 & 4137 & -0.96 \\
\hline $07 N D-1-14 b$ & 2476 & 0.01407 & 0.00050 & 0.280988 & 0.000022 & -63.1 & -8.5 & 0.8 & 3109 & 3496 & -0.98 \\
\hline 07ND-1-15b & 803 & 0.03197 & 0.00134 & 0.282441 & 0.000036 & -11.7 & 5.3 & 1.3 & 1158 & 1363 & -0.96 \\
\hline 07ND-1-16b & 663 & 0.01068 & 0.00040 & 0.280922 & 0.000020 & -65.4 & -51.1 & 0.7 & 3189 & 4746 & -0.99 \\
\hline 07ND-1-18b & 1079 & 0.01905 & 0.00068 & 0.281831 & 0.000031 & -33.3 & -9.9 & 1.1 & 1980 & 2525 & -0.98 \\
\hline 07ND-1-19b & 942 & 0.01405 & 0.00057 & 0.281406 & 0.000021 & -48.3 & -27.9 & 0.7 & 2552 & 3533 & -0.98 \\
\hline 07ND-1-20b & 1461 & 0.01946 & 0.00079 & 0.281544 & 0.000032 & -43.4 & -11.8 & 1.1 & 2378 & 2929 & -0.98 \\
\hline $07 \mathrm{ND}-1-21 \mathrm{~b}$ & 1089 & 0.05388 & 0.00226 & 0.282343 & 0.000023 & -15.2 & 7.3 & 0.8 & 1329 & 1458 & -0.93 \\
\hline 07ND-1-22b & 3505 & 0.01401 & 0.00053 & 0.280561 & 0.000022 & -78.2 & -0.1 & 0.8 & 3678 & 3784 & -0.98 \\
\hline 07ND-1-25b & 1043 & 0.06348 & 0.00232 & 0.282218 & 0.000027 & -19.6 & 1.9 & 1.0 & 1512 & 1764 & -0.93 \\
\hline 07ND-1-26b & 2505 & 0.00446 & 0.00013 & 0.280959 & 0.000021 & -64.1 & -8.2 & 0.7 & 3117 & 3502 & -1.00 \\
\hline $07 \mathrm{ND}-1-27 \mathrm{~b}$ & 1565 & 0.01349 & 0.00051 & 0.281738 & 0.000024 & -36.6 & -2.3 & 0.9 & 2098 & 2424 & -0.98 \\
\hline 07ND-1-30b & 1689 & 0.05765 & 0.00242 & 0.281693 & 0.000033 & -38.2 & -3.3 & 1.2 & 2271 & 2581 & -0.93 \\
\hline 07ND-1-31b & 1053 & 0.01302 & 0.00060 & 0.281824 & 0.000023 & -33.5 & -10.7 & 0.8 & 1986 & 2553 & -0.98 \\
\hline 07ND-1-34b & 1528 & 0.01774 & 0.00067 & 0.281313 & 0.000022 & -51.6 & -18.4 & 0.8 & 2684 & 3384 & -0.98 \\
\hline 07ND-1-35b & 1569 & 0.01893 & 0.00071 & 0.281499 & 0.000023 & -45.0 & -10.9 & 0.8 & 2435 & 2958 & -0.98 \\
\hline 07ND-1-36b & 909 & 0.01090 & 0.00042 & 0.281865 & 0.000023 & -32.1 & -12.3 & 0.8 & 1920 & 2543 & -0.99 \\
\hline 07ND-1-37b & 645 & 0.02274 & 0.00088 & 0.281466 & 0.000024 & -46.2 & -32.4 & 0.8 & 2491 & 3592 & -0.97 \\
\hline 07ND-1-38b & 1001 & 0.01733 & 0.00069 & 0.282435 & 0.000030 & -11.9 & 9.8 & 1.1 & 1146 & 1234 & -0.98 \\
\hline 07ND-1-40b & 1084 & 0.03725 & 0.00137 & 0.281957 & 0.000024 & -28.8 & -5.8 & 0.9 & 1840 & 2276 & -0.96 \\
\hline 07ND-1-42b & 2554 & 0.01301 & 0.00049 & 0.280456 & 0.000031 & -81.9 & -25.6 & 1.1 & 3813 & 4584 & -0.99 \\
\hline 07ND-1-43b & 2421 & 0.01125 & 0.00042 & 0.280770 & 0.000029 & -70.8 & -17.3 & 1.0 & 3391 & 3989 & -0.99 \\
\hline 07ND-1-44b & 2484 & 0.01408 & 0.00055 & 0.281132 & 0.000024 & -58.0 & -3.3 & 0.9 & 2920 & 3186 & -0.98 \\
\hline 07ND-1-45b & 798 & 0.01974 & 0.00072 & 0.281941 & 0.000028 & -29.4 & -12.2 & 1.0 & 1831 & 2454 & -0.98 \\
\hline 07ND-1-47b & 642 & 0.00649 & 0.00029 & 0.281637 & 0.000023 & -40.1 & -26.2 & 0.8 & 2223 & 3205 & -0.99 \\
\hline 07ND-1-48b & 1021 & 0.01761 & 0.00066 & 0.281947 & 0.000027 & -29.2 & -7.1 & 1.0 & 1820 & 2304 & -0.98 \\
\hline 07ND-1-49b & 1705 & 0.00687 & 0.00027 & 0.281727 & 0.000026 & -37.0 & 0.7 & 0.9 & 2100 & 2346 & -0.99 \\
\hline 07ND-1-50b & 3211 & 0.01212 & 0.00055 & 0.280588 & 0.000023 & -77.2 & -6.0 & 0.8 & 3644 & 3909 & -0.98 \\
\hline 07ND-1-52b & 1202 & 0.02107 & 0.00079 & 0.282040 & 0.000031 & -25.9 & 0.1 & 1.1 & 1698 & 1995 & -0.98 \\
\hline 07ND-1-55b & 2854 & 0.01844 & 0.00073 & 0.280509 & 0.000018 & -80.0 & -17.4 & 0.6 & 3766 & 4316 & -0.98 \\
\hline 07ND-1-56b & 955 & 0.03341 & 0.00130 & 0.282118 & 0.000030 & -23.1 & -2.9 & 1.1 & 1611 & 1991 & -0.96 \\
\hline 07ND-1-57b & 850 & 0.04760 & 0.00180 & 0.281622 & 0.000025 & -40.7 & -23.0 & 0.9 & 2333 & 3160 & -0.95 \\
\hline 07ND-1-58b & 623 & 0.01298 & 0.00047 & 0.282023 & 0.000030 & -26.5 & -13.0 & 1.1 & 1707 & 2373 & -0.99 \\
\hline 07ND-1-59b & 2459 & 0.00762 & 0.00030 & 0.280568 & 0.000026 & -77.9 & -23.5 & 0.9 & 3647 & 4386 & -0.99 \\
\hline 07ND-1-60b & 1046 & 0.03652 & 0.00138 & 0.282071 & 0.000025 & -24.8 & -2.6 & 0.9 & 1681 & 2046 & -0.96 \\
\hline 07ND-1-61b & 851 & 0.01719 & 0.00076 & 0.282163 & 0.000024 & -21.5 & -3.2 & 0.9 & 1527 & 1933 & -0.98 \\
\hline 07ND-1-62b & 2297 & 0.02387 & 0.00093 & 0.281269 & 0.000025 & -53.2 & -3.2 & 0.9 & 2762 & 3039 & -0.97 \\
\hline 07ND-1-63b & 1811 & 0.04550 & 0.00179 & 0.281470 & 0.000023 & -46.0 & -7.9 & 0.8 & 2546 & 2955 & -0.95 \\
\hline 07ND-1-64b & 2511 & 0.01253 & 0.00057 & 0.280938 & 0.000023 & -64.9 & -9.6 & 0.8 & 3181 & 3589 & -0.98 \\
\hline 07ND-1-65b & 1061 & 0.02518 & 0.00093 & 0.282243 & 0.000024 & -18.7 & 4.1 & 0.9 & 1422 & 1636 & -0.97 \\
\hline 07ND-1-66b & 2416 & 0.00762 & 0.00030 & 0.280975 & 0.000021 & -63.5 & -10.0 & 0.7 & 3109 & 3540 & -0.99 \\
\hline 07ND-1-68b & 2532 & 0.01384 & 0.00054 & 0.280839 & 0.000020 & -68.4 & -12.6 & 0.7 & 3311 & 3786 & -0.98 \\
\hline
\end{tabular}



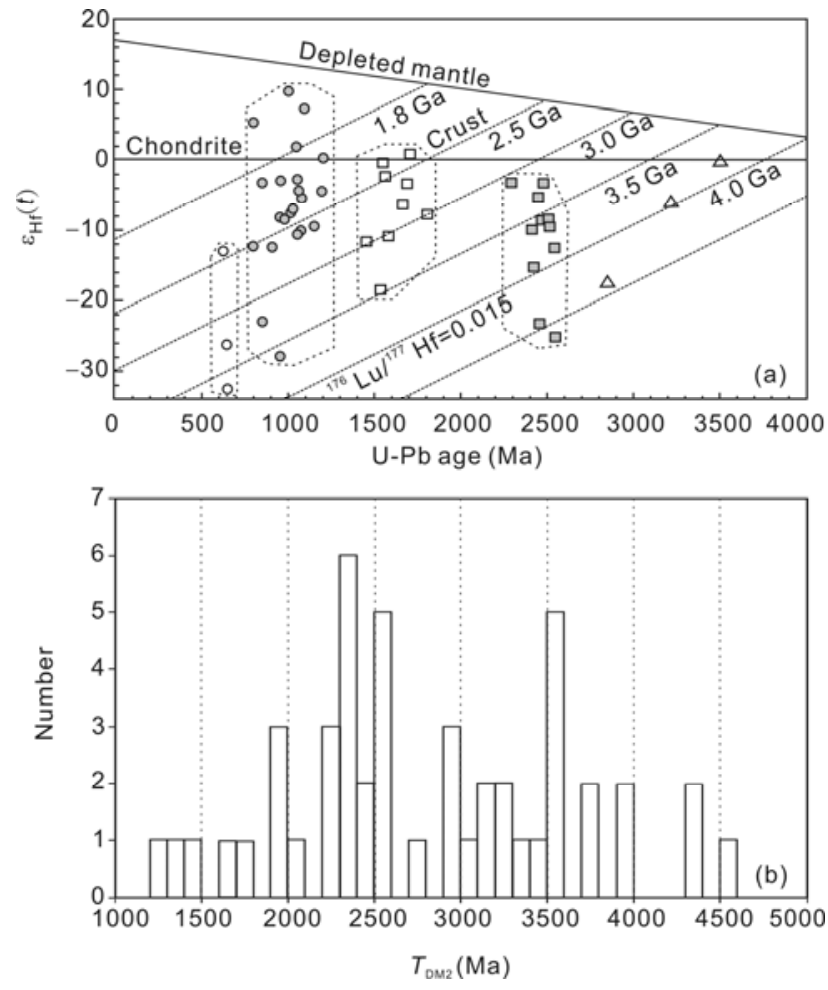

Figure 4 Hf isotopic feature (a) and Hf two-stage model ages histogram (b) of detrital zircons from garnet-mica-quartz schist of the Ningduo Rock Group.

values between 2373-3592 Ma. Finally, a few zircons with ages around $2854-3505 \mathrm{Ma}$ showed low ${ }^{176} \mathrm{Hf} /{ }^{177} \mathrm{Hf}$ ratios $(0.280509-0.280588)$ and negative $\varepsilon_{\mathrm{Hf}}(t)(-0.1$ to -17.4$)$, and the $T_{\mathrm{DM} 2}$ yielded ages from 3784 to $4316 \mathrm{Ma}$.

\section{Discussion}

The U-Pb ages of the garnet-mica quartz schist in the Ningduo Rock Group of the Longbao area concentrated in four groups - 2600-2300 Ma, 1700-1400 Ma, 1200-850 $\mathrm{Ma}$ and 700-530 Ma - and their peak ages were $2440 \mathrm{Ma}$, $\sim 1532 \mathrm{Ma}, \sim 982 \mathrm{Ma}$ and $\sim 618 \mathrm{Ma}$, respectively. The first peak age of $\sim 982 \mathrm{Ma}$ was consistent with the Grenville orogeny (1190-980 Ma) [41-43] caused by convergence of Rodinia. The second peak age of $\sim 618 \mathrm{Ma}$ was the youngest age of the erosion source area, and was close to the Pan-African Movement (roughly between 600-550 Ma) $[44,45]$. These results indicate that some of the zircons of the Ningduo Rock Group came from a source that experienced the Pan-African event. These zircons with young ages also constrained the lower limit of the deposition time of this stratum. In other words, these zircons likely formed in the late Neoproterozoic. The zircons with age peaks of $\sim 2440 \mathrm{Ma}$ and $\sim 1532 \mathrm{Ma}$ were rounded, developed wide internal zonation, and had high $\mathrm{Th} / \mathrm{U}$ ratios. This indicates that they came from a source that experienced tectonomagmatic events that occurred about $2440 \mathrm{Ma}$ and $1532 \mathrm{Ma}$ ago.

In addition, there were a few ancient detrital zircons with ages older than $3100 \mathrm{Ma}$, among which is the oldest one with a ${ }^{207} \mathrm{~Pb} /{ }^{206} \mathrm{~Pb}$ age of $3981 \pm 9 \mathrm{Ma}$, as well as others with ${ }^{207} \mathrm{~Pb} /{ }^{206} \mathrm{~Pb}$ ages of $3505 \pm 18 \mathrm{Ma}, 3450 \pm 8 \mathrm{Ma}, 3211 \pm 20 \mathrm{Ma}$ and $3127 \pm 10 \mathrm{Ma}$. For zircons with ages of $3981 \pm 9 \mathrm{Ma}$, this is the oldest record of the crust that has been discovered in the Qiangtang area, and it also is the third oldest zircon that has been discovered in China, after that in Tibet and Qinling. These results indicate that there residual Hadean signatures are preserved in Northern Qiangtang. This information is crucial to studies of crustal rocks and evolution of early Earth.

Zircon $\mathrm{U}-\mathrm{Pb}$ dating and $\mathrm{Hf}$ isotopic analyses have provided important information regarding the study of the growth and recycling of continental crust $[46,47]$. Hf model ages indicate that the age of the magma source in the Qiantang area is the growth age of the crust, at the time it separated from the depleted mantle. However, most zircons did not form directly via mantle differentiation from parent magma. Thus, in this case, the two-stage model of ages is more closely related to the growth age of the crust. The Hf isotopic results indicate that zircons with ages of $\sim 982 \mathrm{Ma}$ produced a negative $\varepsilon_{\mathrm{Hf}}(t)$, and the two-stage model of ages yielded an age of about 1933-2553 Ma, which verifies that there may have been initial crust in the Paleoproterozoic in the source area of the Ningduo Rock Group. A few zircons with ages around 2854-3505 Ma also showed a negative $\varepsilon_{\mathrm{Hf}}(t)$, and the $T_{\mathrm{DM} 2}$ yielded ages within $3784-4316 \mathrm{Ma}$. This information indicates that the source area of the Ningduo Rock Group was much older (Hadean) crust than the residue, which is consistent with the zircon age of $3981 \pm 9 \mathrm{Ma}$. These results probably indicate that there were crustal materials of the initial formation stage of the Earth in the Changdu Block of Northern Qiangtang. It is difficult to confirm from the source area of these zircons, but based on the two-stage model of ages and the negative $\varepsilon_{\mathrm{Hf}}(t)$, their source may have been TTG rocks that intruded into the crust after separating from the depleted mantle during the Hadean.

Presently, there is great controversy regarding whether Precambrian basement existed in Qiangtang. Most researchers have believed that the basement of the Qiangtang consists of two-layered Proterozoic metamorphic rocks [48-51]. Nonetheless, Wang et al.[52] indicated that there probably was an Archean continental core in the Qiangtang area. Based on combined data sets of zircon $\mathrm{U}-\mathrm{Pb}$ and $\mathrm{Rb}-\mathrm{Sr}$ isotopic ages (318-384 Ma) and a field survey of the Qiangtang area, Li [53] suggested that the main time of formation of the epimetamorphic rocks in central Qiangtang was that of the late Carboniferous. However, the 1:250000 regional geological survey obtained some ages for Jiningian in Eastern Qiangtang. In recent years, SHRIMP U-Pb ages of cumulate gabbros have revealed age clusterings around $438 \pm 11 \mathrm{Ma}$ [54], which is useful for determination of the Ordovician ophiolite in the hinterland of Qiangtang. Based 
on the youngest age of $\sim 618 \mathrm{Ma}$ and regional geological features, we suggest that the Ningduo Rock Group formed in the late Neoproterozoic to Palaeozoic.

It is worth mentioning that detrital zircons with ages of 4.0-4.1 Ga were discovered in Pulan County and Western Nepal in the Himalayas, and a number of ages consistent with Pan-African events were reported [55-57]; whereas, the Himalayan-Gangdese region has been considered to belong to East Gondwana. Based on $\mathrm{U}-\mathrm{Pb}$ ages and $\mathrm{Lu}-\mathrm{Hf}$ isotopic studies on metamorphic rocks of the late Neoproterozoic in the Cathaysia Block, Yu et al. [58] obtained many detrital zircon ages for the Grenville ( 1.0 Ga), Neoarchean, and a few ages in the Eoarchean $(\sim 3.8 \mathrm{Ga})$, PaleoMesoar-chean (3.3-3.0 Ga), Paleoproterozic (1.7-1.4 Ga), Mesoproterozoic (1.7-1.4 Ga) and Pan-Africa (0.70-0.54 $\mathrm{Ga}$ ) intervals. They believed that the source was mainly Eastern India-Eastern Antarctic, and suggested that the southern margin of the South China Block was close to India and Eastern Antarctic in the period of the Rodinian divergence and Gondwanan convergence. Other than the zircon age of $3.98 \mathrm{Ga}$, many ages in the Grenville ( 980 Ma) and Pan-Africa ( 618 Ma) intervals were obtained. We speculate that there were similarities between the Changdu Block and Gondwana. Thus, it is important to study the relationship between the basements of Qiangtang and that of the Gangdese and Himalayan areas to further confine the northern boundary of Gondwana.

\section{Conclusions}

(1) For detrital zircons collected from garnet-mica quartz schist of the Ningduo Rock Group in Changdu Block, northern Qiangtang, ages of $3981 \pm 9 \mathrm{Ma}$ and $3505 \pm 18$ to $3127 \pm 10$ Ma tested by LA-ICP-MS revealed that there were ancient crustal residues in the Changdu Block.

(2) Detrital zircon ages of the Ningduo Rock Group mainly clustered in four groups - 2600-2300 Ma, 1700$1400 \mathrm{Ma}, 1200-850 \mathrm{Ma}$ and 700-530 Ma - with age peaks of $\sim 2440 \mathrm{Ma}, \sim 1532 \mathrm{Ma}, \sim 982 \mathrm{Ma}$ and $\sim 618 \mathrm{Ma}$, respectively. The first peak at $\sim 982 \mathrm{Ma}$ is consistent with the Grenville orogeny caused by convergence of Rodinia, and the second peak of $618 \mathrm{Ma}$ is roughly consistent with the Pan-African Movement, which resulted from convergence of Gondwana. These data indicate that there was a relationship between the Changdu Block and Gondwana. This new evidence is of great importance with respect to understanding the relationship between the basement of the Qiangtang and that of Gangese and Himalayan.

(3) The youngest detrital zircon age was $\sim 618 \mathrm{Ma}$ in the Ningduo Rock Group, which may constrain the lower boundary of the stratum from late Neoproterozoic to early Paleozoic.

(4) Detrital zircons with ages of $\sim 982$ Ma were negative in $\varepsilon_{\mathrm{Hf}}(t)$, and the two-stage Hf model of ages yielded about
1933-2553 Ma. These results suggest that the source area of the Ningduo Rock Group was separated into crust from the depleted mantle during the Paleoproterozoic. In other words, there were crustal growth events in the Paleoproterozoic. However, zircons with ages of 2854-3505 Ma showed a negative $\varepsilon_{\mathrm{Hf}}(t)$ and their two-stage $\mathrm{Hf}$ models of ages were around 3784-4316 Ma, which demonstrates that there still were much older (Hadean) crustal residues in the source area of the Ningduo Rock Group.

The authors thank Professors Wu Yuanbao and Li Cai, Researcher Wan Yusheng, and Drs. Wang Hongliang and Diwu Chunrong for their constructive suggestions. The authors also thank Professors Liu Xiaoming and Yuan Honglin, Zha Xianfeng, Gong Hujun, Dai Mengning, Li Ping, Wu Peng, Tang Zhuo and Zhu Tao for their help with laboratory tests. This English version was translated by Zha Xianfeng and Xu Lily, and was modified by Yang Zhao. This work was supported by the China Geological Survey Project "An Integrated Study on Precambrian Geology and Paleozoic Tectono-Palaeogeography in Tibetan Plateau” (1212010610102).

1 Wu F Y, Yang J H, Liu X M, et al. Hf isotopes of the 3.8 Ga zircons in eastern Hebei Province, China: Implications for early crustal evolution of the Northern China Craton. Chinese Sci Bull, 2005, 50: 2473-2480

2 Gradstein F M, Ogg J G, Smith A G, et al. A new Geologic Time Scale, with special reference to Precambrian and Neogene. Episodes, 2004, 27: 83-100

3 Lu S N, Wang H C, Li H K. Unscramble the ISC 2004 and special reference to Precambrian from 2004 to 2008 (in Chinese). J Strat, 2005, 25: 180-187

4 Kinny P D. 3820 Ma zircons from a tonalitic Armîsoq gneiss in the Godthåb district of Southern West Greenland. Earth Planet Sci Lett, 1986, 79: 337-347

5 Nutman A P, Mojzsis S J, Friend C R L. Recognition of $\geqslant 3850$ Ma water-lain sediments in West Greenland and their significance for the early Archaean Earth. Geochim Cosmochim Acta, 1997, 61: 2475-2484

6 Bowring S A, Housh T B, Isachsen C E. The Acasta gneisses: Remnant of Earth's early crust. In: Newsom H E, Jones J H, eds. Origin of the Earth. New York: Oxford University Press, 1990. 319-343

7 Iizuka T, Horie K, Komiya T, et al. 4.2 Ga zircon xenocryst in an Acasta gneiss from northwestern Canada: Evidence for early continental crust. Geology, 2006, 34: 245-248

8 Liu D Y, Nutman A P, Compston W, et al. Remnants of $3800 \mathrm{Ma}$ crust in the Chinese part of the Sino-Korean Craton. Geology, 1992, 20: $339-342$

9 Song B, Nutman A P, Liu D Y, et al. 3800 to 2500 Ma crust in the Anshan area of Liaoning Provence, northeastern China. Precambrian Res, 1996, 78: 79-94

10 Wan Y S, Liu D Y, Song B, et al. Geochemical and Nd isotopic compositions of $3.8 \mathrm{Ga}$ meta-quartz diorite and trondhjemitie rocks from the Anshan area and their geological significance. J Asian Earth Sci, 2005, 24: 563-575

11 Black L P, Williams I S, Compston W. Four zircon ages from one rock: The history of a 3930 Ma old granulite from Mount Sones, Enderby Land, Antarctica. Contrib Mineral Petrol, 1986, 94: 427-437

12 Harley S L, Black L P. A revised Archean chronology for the Napier Complex, Enderby Land, from SHRIMP ion-microprobe studies. Antar Sci, 1997, 9: 74-91

13 Choi S H, Mukasa S B, Andronikov A V, et al. Lu-Hf systematics of the ultra-high temperature Napier Metamorphic Complex in Antarctica: Evidence for the early Archean differentiation of Earth's mantle. Earth Planet Sci Lett, 2006, 246: 305-316

14 Sano Y, Terada K, Hidaka H, et al. Palaeoproterozoic thermal events recorded in the $\sim 4.0 \mathrm{Ga}$ Acasta gneiss, Canada: Evidence from SHRIMP U-Pb dating of apatite and zircon. Geochim Cosmochim 
Acta, 1999, 63: 899-905

15 Nutman A P, Friend C R L, Bennett V C. Review of the oldest (4400 3600 Ma) geological and mineralogical record: Glimpses of the beginning. Episodes, 2001, 24: 93-101

16 Gebauer D, Williams I S, Compston W, et al. The development of the Central European Continental crust since the Early Archaean based on conventional and ion-microprobe dating of up to 3.84 b.y. old detrital zircons. Tectonophysics, 1989, 157: 81-96

17 Mueller P A, Wooden J L, Nutman A P, et al. Early Archean crust in the northern Wyoming province: Evidence from $\mathrm{U}-\mathrm{Pb}$ ages of detrital zircons. Precambrian Res, 1998, 91: 295-307

18 Wilde S A, Valley J W, Peck W H, et al. Evidence from detrital zircons for the existence of continental crust and oceans on the Earth 4.4 Ga ago. Nature, 2001, 409: 175-178

19 Hartmann L A, Endo I, Suita M T F, et al. Provenance and age delimitation of Quadrilátero Ferrífero sandstones based on zircon U-Pb isotopes. J South Am Earth Sci, 2006, 20: 273-285

20 Gehrels G E, DeCelles P G, Ojha T P, et al. Geologic and U-Pb geochronologic evidence for early Paleozoic tectonism in the Dadeldhura thrust sheet, far-west Nepal Himalaya. J Asian Earth Sci, 2006, 28: 385-408

21 Kröner A, Hegner E, Lehmann B, et al. Palaeozoic arc magmatism in the Central Asian Orogenic Belt of Kazakhstan: SHRIMP zircon ages and whole-rock Nd isotopic systematics. J Asian Earth Sci, 2008, 32: $118-130$

22 Wu F Y, Yang J H, Liu X M, et al. Nd isotopic constrains on crustal formation in the North China Craton. J Asian Earth Sci, 2005, 24: 523-545

23 Wilde S A, Valley J W, Kita N T, et al. SHRIMP U-Pb and CAMECA 1280 oxygen isotope results from ancient detrital zircons in the Caozhuang Quartzite, eastern Hebei, North China Craton: Evidence for crustal reworking 3.8 Ga ago. Am J Sci, 2008, 308: 185-199

24 Wen C Q, Duo J, Fan X P, et al. Detrital Zircon of 4100 Ma in Quartzite in Burang, Tibet (in Chinese). Acta Geol Sin, 2006, 80: 1249-1251

25 Duo J, Wen C Q, Guo J C, et al. 4.1 Ga old detrital zircon in western Tibet of China. Chinese Sci Bull, 2007, 52: 23-26

26 Zhang S B, Zheng Y F, Wu Y B, et al. Zircon U-Pb age and Hf isotope evidence for $3.8 \mathrm{Ga}$ crustal remnant and episodeic reworking of Archean crust in South China. Earth Planet Sci Lett, 2006, 252: 56-71

27 Wang H L, Chen L, Sun Y, et al. 4.1 Ga xenocrystal zircon from Ordovician volcanic rocks in western part of North Qinling orogenic belt. Chinese Sci Bull, 2007, 52: 3002-3010

28 Zheng J P, Griffin W L, Tang H Y, et al. Archean basement similar to the North China and Yangtze Continents may be existed beneath the Western Cathaysia (in Chinese). Geol J Chin Univ, 2008, 14: 549-557

29 Hao Z W, Rao R B. The Regional Stratigraphy of the Southwest China (in Chinese). Wuhan: China University of Geosciences Press, 1989

30 Dengke Unit of Tibet Bureau of Geological and Mineral Investigation. 1:200000 Scale Dengke Regional Geological Survey Report (in Chinese). 1994

31 The 4th Unit of Sichuan Bureau of Geological and Mineral Investitation. 1:200000 scale Leiwuqi and Laduo Regional Geological Survey Report (in Chinese). 1994

32 Geological Survey of Qinghai. 1:250000 Scale Zhiduo County Regional Geological Survey Report (in Chinese). 2006

33 Geological Survey of Qinghai. 1:250000 Scale Qurougaka Regional Geological Survey Report (in Chinese). 2005

34 Li R S, Ji W H, Pan X P, et al. 1:1000000 Scale Geological Map of Kunlun Mountains and Its Adjacent Areas (in Chinese). Beijing: Geological Publishing House, 2008

35 Xi'an Institute of Geology and Mineral Resources. 1:250000 Scale Yushu Regional Geological Survey Report (in Chinese). 2006

36 Andersen T. Correction of common lead in $\mathrm{U}-\mathrm{Pb}$ analyses that do not report ${ }^{204} \mathrm{~Pb}$. Chem Geol, 2002, 192: 59-79
37 Ludwig K R. Isoplot 3.0-A geochronologycal toolkit for Micro-soft Excel. Berkeley Geochronology Certer Spec Pub, 2003, 4: 1-70

38 Gao S, Liu X M, Yuan H L, et al. Analysis of forty-two major and trace elements of USGS and NIST SRM Glasses by LA-ICPMS. Geostand Newsl, 2002, 22: 181-195

39 Yuan H L, Wu F Y, Gao S, et al. Determination of U-Pb age and rare earth element concentration zircons from Cenozoic intrusions in northeastern China by laser ablation ICP-MS. Chinese Sci Bull, 2003, 48: 2411-2421

40 DiWu C R, Sun Y, Yuan H L, et al. U-Pb ages and Hf isotopes for detrital zircons from quartzite in the Paleoproterozoic Songshan Group on the southwestern margin of the North China Craton. Chinese Sci Bull, 2008, 53: 2828-2839

41 Riveis T. Lithotectonic elements of the Grenville Province: Review and tectonic implication. Precambrian Res, 1997, 86 : 117-154

42 Lu S N. From Rodinia to Gondwanaland supercontinents-Thinking about problems of researching neoproterozoic supercontinents (in Chinese). Earth Sci Front, 2001, 8: 441-448

43 Hao J, Zhai M G. Jinning Movement and Sinian system in China: Their relationship with Rodinia supercontinent (in Chinese). Chin J Geol, 2004, 39: 139-152

44 Kröner A. The Pan-African belt of northeastern and eastern Africa, Madagascar, southern India, Sri Lanka and East Antarctic: Terrane amalgamation during formation of the Gondwana supercontinent. In: Thorweihe U, Schandelmeier H, eds. Geoscientific Research in Northeast Africa, Balkema, Rotterdam, 1993. 3-9

45 Lu S N. Comparison of the Pan-Cathaysian orogeny with the Caledonian and Pan-African orogenies (in Chinese). Geol Bull Chin, 2004, 23: 952-958

46 Wu F Y, Li X H, Zheng Y F, et al. Lu-Hf isotopic systematics and their applications in petrology (in Chinese). Acta Petrol Sin, 2007, 23: $185-220$

47 Zheng Y F, Zhang S B. Formation and evolution of Precambrian continental crust in South China. Chinese Sci Bull, 2007, 52: 1-12

48 Wang C S, Yi H S, Li Y, et al. Geological Evolution and Oil-Gas prospect Evaluation in the Qiangtang Basin, Tibet (in Chinese). Beijing: Geological Publishing House, 2001. 1-59

49 Huang J J. Tectonic characteristics and evolution of the Qiangtang basin (in Chinese). Reg Geol Chin, 2001, 20: 178-186

50 Huang J J. Structural characteristics of the basement of the Qiangtang basin (in Chinese). Acta Geol Sin, 2001, 75: 333-337

51 Zhao Z Z, Li Y T, Luo J N, et al. The Strata in Qinghai-Tibet Plateau (in Chinese). Beijing: Science Press, 2001. 10-30

52 Wang G Z, Wang C S. Disintegration and age of basement metamorphic rocks in Qiangtang, Tibet, China. Sci China Earth Sci, 2001, 44: 86-93

53 Li C. Question about the basement of the Qiangtang Micro-plate (in Chinese). Geol Rev, 2003, 49: 4-9

54 Li C, Dong Y S, Zhai Q G, et al. Discovery of Eopaleozoic ophiolite in the Qiangtang of Tibet Plateau: Evidence from SHRIMP U-Pb dating and its tectonic implications (in Chinese). Acta Petrol Sin, 2008, 24: $31-36$

55 Xu Z Q, Yang J S, Liang F H, et al. Pan-African and Early Paleozoic orogenic events in the Himalaya terrane: Inference from SHRIMP $\mathrm{U}-\mathrm{Pb}$ ziron ages (in Chinese). Acta Petrol Sin, 2005, 21: 1-12

56 Song S G, Ji J Q, Wei C J, et al. Early Paleozoic granite in Nujiang River of northwest Yunnan in southwestern China and its tectonic implications. Chinese Sci Bull, 2007, 52: 2402-2406

57 Li C, Xie R W, Sha S L, et al. SHRIMP U-Pb zircon dating of the Pan-African granite Baxoi County, eastern Tibet, China (in Chinese). Geol Bull Chin, 2008, 27: 64-68

58 Yu J H, Suzanne Y O, Wang L J, et al. Where was South China in the Rodinia supercontinent? Evidence from U-Pb geochronology and $\mathrm{Hf}$ isotopes of detrital zircons. Precambrian Res, 2008, 164: 1-15

Open Access This article is distributed under the terms of the Creative Commons Attribution License which permits any use, distribution, and reproduction in any medium, provided the original author(s) and source are credited. 